\title{
KOMUNIKASI PEMASARAN PT MUSTIKA RATU CABANG PEKANBARU DALAM MENGHADAPI PERSAINGAN PASAR
}

\author{
Dicky Novaldy, S.I.Kom ${ }^{1}$ \& Dyah Pithaloka, M.Si²
}

\author{
Fakultas Ilmu Komunikasi Universitas Islam Riau \\ Jl. Kaharudin Nasution no.113 Pekanbaru, 28284 - Indonesia \\ Email: pithaloka@comm.uir.ac.id
}

\begin{abstract}
Abstrak
Penelitian ini bertujuan untuk mengetahui komunikasi pemasaran PT Mustika Ratu Cabang Pekanbaru dalam menghadapi persaingan pasar kosmetik. Penelitian ini menggunakan metode kualitatif dengan penyajian secara deskriptif. Data dikumpulkan melalui pengamatan, wawancara, dan dokumentasi. Subjek penelitian ini terdiri dari 5 orang. Subjek utama dipilih menggunakan teknik purposive sampling. Untuk menganalisa hasil penelitian ini menggunakan teknik analisis data interaktif. Hasil penelitian ini menunjukkan bahwa langkah pertama PT Mustika Ratu Cabang Pekanbaru dalam menghadapi persaingan pasar kosmetik adalah dengan menggunakan segmentasi, targeting, positioning. Setelah itu, PT Mustika Ratu Cabang Pekanbaru menggunakan strategi komunikasi pemasaran terpadu atau yang dikenal dengan sebutan Integrated Marketing Communication (IMC) yang terdiri dari periklanan, promosi penjualan, personal selling, direct marketing, publisitas dan hubungan masyarakat, serta acara dan pengalaman komunikasi pemasaran PT Mustika Ratu Cabang Pekanbaru. Faktor yang mempengaruhi kegiatan komunikasi pemasaran PT Mustika Ratu Cabang Pekanbaru yakni periklanan di televisi yang kurang, kurangnya karyawan, pemberian sampel yang kurang, dan macetnya pendistribusian produk ke toko.
\end{abstract}

Kata kunci : komunikasi pemasaran, persaingan pasar

\begin{abstract}
This study aims to determine marketing communications PT Mustika Ratu Pekanbaru Branch in the face of cosmetic market competition. This research uses qualitative method with descriptive presentation. Data were collected through observation, interviews, and documentation. The subjects of this study consisted of 5 people. The main subject was chosen using purposive sampling technique. To analyze the results of this study using interactive data analysis techniques. The results of this study indicate that the first step of PT Mustika Ratu Pekanbaru Branch in the face of cosmetic market competition is to use segmentation, targeting, positioning. After that, PT Mustika Ratu Pekanbaru Branch uses integrated marketing communications strategy or known as Integrated Marketing Communication (IMC) consisting of advertising, sales promotion, personal selling, direct marketing, publicity and public relations, as well as events and marketing communications experience PT Mustika Ratu Pekanbaru Branch. Factors affecting marketing communications activities of PT Mustika Ratu Pekanbaru Branch ie less television advertising, lack of employees, less sampling, and stalled distribution of products to the store.
\end{abstract}

Keywords: Marketing communications, market competition 



\section{PENDAHULUAN}

Kosmetik sebagai salah satu penunjang penampilan menjadi kebutuhan yang hamper primer bagi banyak kalangan. Tidak saja wanita, sekarang ini pun para pria sudah sangat peduli dengan penampilannya, sehingga perusahaan-perusahaan yang bergerak di bidang kosmetik memproduksi kosmetik khusus para pria. Kosmetik tidak hanya meliputi perlengkapan make-up, melainkan juga perawatan tubuh dan wajah, misalnya: sabun mandi, shampoo, sabun pencuci muka.

Begitu pentingnya kosmetik bagi seseorang untuk menunjang penampilan membuat industri yang bergerak dibidang kosmetik berlombalomba untuk memasarkan produknya. Agar masyarakat menggunakan produk mereka, setiap perusahaan harus memiliki cara yang unik untuk dapat menarik perhatian masyarakat agar memilih produknya, salah satu cara yaitu dengan melakukan komunikasi pemasaran dengan kegiatan periklanan, promosi penjualan, publisitas dan hubungan masyarakat, penjualan pribadi ataupun dengan pemasaran langsung.

Dalam prakteknya, sebaik apapun ide seseorang jika ia tak mampu mengomunikasikannya dengan baik dan benar, maka ide tersebut tidak akan terealisasi, karena komunikasi yang baik harus dapat dipahami oleh kedua belah pihak dan hal ini berhubungan dalam pengambilan keputusan seseorang. Komunikasi pemasaran terpadu adalah kegiatan yang berupaya memadukan antara periklanan dengan alat-alat komunikasi pemasaran lainnya seperti humas, pemasaran langsung, promosi penjualan, serta penjualan personal untuk bisa bekerja bersamasama menyampaikan pesan yang jelas, konsisten, dan berpengaruh kuat (Kotler \& Armstrong, 2008:138).
PT Mustika Ratu adalah salah satu perusahaan nasional yang bergerak dalam industri pembuatan kosmetik, jamu, dan bahan-bahan kecantikan. PT Mustika Ratu sudah cukup terkenal dan sudah cukup lama berdiri di Indonesia. PT Mustika Ratu berdiri dari 14 Maret 1978. Pada awal produksinya, Mustika Ratu hanya membuat 5 macam jamu, beberapa lulur dan kosmetik tradisional lain seperti mangir, bedak dingin dan air mawar. Sejalan dengan penambahan karyawan pada tahun-tahun berikutnya, PT Mustika Ratu juga menambah beberapa varian produknya. Produkproduk Mustika Ratu mulai didistribusikan ke toko-toko melalui salon-salon kecantikan yang meminta menjadi agen sejak tahun 1978 mulai dari Jakarta, Semarang, Surabaya, Bandung, dan Medan. Diantara banyaknya varian produk Mustika Ratu, namun yang menjadi produk andalannya adalah Slimming Tea Mustika Ratu, lulur Ratu Mas, Puteri BodySplash dan hand and body Puteri.

Oleh karena banyaknya pesaing PT Mustika Ratu Cabang Pekanbaru di bidang kosmetik, PT Mustika Ratu memerlukan strategi komunikasi pemasaran yang tepat agar bisa mengadapi persingan pasar kosmetik. Karena itu, peneliti ingin mengajukan penelitian yang berkaitan dengan komunikasi pemasaran untuk menghadapi persaingan perusahaan yang bergerak di bidang kosmetik. Alasan inilah yang menjadikan peneliti tertarik untuk meneliti bagaimana strategi komunikasi pemasaran PT Mustika Ratu Cabang Pekanbaru Dalam Menghadapi Persaingan Pasar Kosmetik dan factor apa saja yang mempengaruhi.

Penelitian ini diharapkan Penelitian ini diharapkan dapat menjadi panduan bagi peneliti dimasa yang akan datang khususnya yang membahas komunikasi pemasaran. Selain itu, penelitian ini diharapkan dapat 
menambah wawasan, pengetahuan dan keterampilan yang relevan untuk dapat meningkatkan kompetensi dan kecerdasan intelektual khususnya dalam mengetahui strategi komunikasi pemasaran. Dari segi praktis, penelitian ini diharapkan dapat bermanfaat bagi PT Mustika Ratu Cabang Pekanbaru sebagai tolak ukur akan penyampaian komunikasi pemasaran dalam menghadapi persaingan pasar kosmetik. Serta dapat menjadi masukan dan referensi bagi PT Mustika Ratu dalam melakukan evaluasi dan perbaikan terhadap strategi komunikasi pemasaran dalam menghadapi pasar kosmetik lain.

\section{KERANGKA TEORI}

\section{Komunikasi Pemasaran}

Menurut Shimp (2003:4) komunikasi pemasaran dapat dipahami dengan menguraikan dua unsur pokok yaitu komunikasi dan pemasaran. Komunikasi adalah dimana proses pemikiran dan pemahaman disampaikan antar individu. Komunikasi sangat penting bagi keberhasilan dalam proses pertukaran. Pada tingkatnya, komunikasi dapat menginformasikan dan membuat konsumen potensialnya menyadari atas keberadaan produk yang ditawarkan.

Komunikasi pemasaran adalah kegiatan komunikasi yang bertujuan untuk menyampaikan pesan pada konsumen dengan menggunakan berbagai media, dengan harapan agar komunikasi dapat menghasilkan tiga tahap perubahan, pengetahuan, perubahan sikap, dan perubahan yang dikehendaki. Adapun jenis media yang digunakan adalah surat kabar, brosur, spanduk,dan lain-lain. Menurut Alifahmi (2005:3) sedikitnya ada tiga sisi menarik dari perkembangan terbaru komunikasi pemasaran, yaitu:

1. Strategi yang ditawarkan begitu segar, menyodorkan trobosan baru yang mengkombinasikan iklan, promosi, dan kehumasan sebagai alternatif dari pada pradigma lama yang lebih mengedepankan iklan dan promosi sebagai bintang.

2. Pendekatannya bersifat holistic (menyeluruh), tidak terlihat suatu persoalan secara terpisah-pisah, tetapi merangkai berbagai pihak terkait (stakeholders) baik internal organisasi maupun semua pihak luar yang berkepentingan atau terkenak dampak.

3. Keluwesannya dalam memadukan berbagai disiplin ilmu dan jenjang personil yang menjalankan fungsi yang berbeda-beda untuk menghasilkan sinergi.

Komunikasi pemasaran terus berkembangan pesat di era ini dan memberikan pencerahan bagi pelaku komunikasi, pemasaran, bahkan di kalangan akademis. pencerahan ini terus berkembang dalam hal ini pembaruan konsep dan penerapannya, serta semakin luasnya profesi yang bergerak dibidang ini.

\section{Strategi Komunikasi Pemasaran Terpadu (Integrate Marketing Communication)}

Komunikasi pemasaran terpadu (Integrate Marketing Communication) didefinisikan oleh Shimp (2003:231) sebagai sebuah proses komunikasi yang terdiri dari perencanaan, kreasi, integrasi dan implementasi atas berbagai bentuk komunikasi pemasaran yang dilakukan secara berkala terhadap prospek dan target konsumen dari sebuah merek. Perbedaan komunikasi pemasaran dan komunikasi pemasaran terpadu terletak pada penggunaannya. Jika komunikasi pemasaran adalah sarana perusahaan untuk menginformasikan, membujuk dan mengingatkan konsumen secara langsung maupun tidak langsung tentang produk dan merek yang mereka jual. Maka komunikasi pemasaran 
terpadu adalah konsep atau proses dimana perusahaan memadukan seluruh alat-alat komunikasi untuk mencapai suatu tujuan. Komunikasi pemasaran terpadu mengganggap seluruh sumber yang dapat menghubungkan pelanggan atau calon dengan produk atau jasa dari suatu merek atau perusahaan, adalah jalur yang potensial untuk menyampaikan pesan di masa datang. Dengan kata lain, proses komunikasi pemasaran terpadu berawal dari pelanggan atau calon pelanggan kemudian berbalik kepada perusahaan untuk menentukan bentuk dan metode yang digunakan dan dikembangkan bagi program yang dijalankannya.

Model komunikasi pemasaran terpadu mencoba untuk menintegrasikan semua unsur bauran promosi dengan asumsi bahwa tidak ada satupun unsur yang terpisah dalam mencapai tujuan pemasaran yang efektif. Adapun berbagai unsur komunikasi pemasaran terpadu menurut Kotler (dalam Hermawan, 2012:56) dapat di jabarkan sebagai berikut:

\section{Periklanan}

Periklanan adalah komunikasi yang dibayar, yang digunakan untuk mengembangkan sikap, menciptakan kesadaran dan mengirimkan informasi untuk mendapatkan respon dari target pasar. semua bentuk penyajian nonpersonal dan promosi ide, barang atau jasa yang dibayar oleh suatu sponsor tertentu

\section{Promosi Penjualan}

Promosi penjualan adalah insentif jangka pendek untuk mendorong pembelian atau penjualan produk atau jasa. Promosi penjualan merupakan berbagai insetif jangka pendek untuk mendorong keinginan mencoba atau membeli suatu produk atau jasa.

3. Hubungan Masyarakat dan Publisitas
Membangun hubungan baik dengan berbagai masyarakat perusahaan dengan memperoleh publisitas yang diinginkan, membangun citra perusahaan yang baik, dan menangani atau menghadapi rumor, cerita, dan kejadian tak menyenangkan. Hubungan Masyarakat dan Publisitas merupakan berbagai program untuk mempromosikan dan/atau melindungi citra perusahaan atau produk individualnya.

\section{Penjualan Personal}

Penjualan personal adalah presentasi pribadi oleh wiraniaga perusahaan dengan tujuan melakukan penjualan dan membangun hubungan dengan pelanggan. Jadi penjualan personal merupakan kegiatan perusahaan untuk melakukan kontak langsung dengan para calon konsumen. Interaksi langsung dengan satu calon pembeli atau lebih untuk melakukan presentasi, menjawab pertanyaan, dan ,menerima pesanan.

\section{Pemasaran Langsung}

Pemasaran langsung (direct marketing) adalah hubungan langsung dengan konsumen individual yang ditargetkan ditargetkan secara hati-hati untuk meraih respon segera dan mencapai hubungan pelanggan yang abadi. Pemasar berkomunikasi langsung dengan pelanggan, baik satu per satu dan berbasis interaktif. Bisa melalui penggunaan surat, telepon, faksimili, email, dan alat penghubung nonpersonal lain untuk berkomunikasi secara langsung dengan atau mendapatkan tanggapan langsung dari pelanggan tertentu dan calon pelanggan.

Selain itu, Philip Kotler (dalam Morissan 2010:55-74) mengatakan ada 3 langkah yang harus dilakukan agar komunikasi pemasaran berhasil yakni dengan menggunakan Segmentasi, Targetting dan Positioning (STP) 


\section{Segmentasi}

Segmentasi pada dasarnya adalah suatu strategi untuk memahami struktur konsumen. Segmentasi diperlukan agar perusahaan dapat melayani konsumennya secara lebih baik, melakukan komunikasi yang lebih persuasif dan yang terpenting adalah memuaskan kebutuhan dan keinginan konsumen yang dituju untuk memasarkan suatu produk, praktisi pemasaran harus tahu siapa yang akan menjadi konsumennya.

\section{Targeting}

Targeting atau menemukan strategi pasar adalah persoalan bagaimana memilih, menyeleksi dan menjangkau konsumen yang akan menjadi fokus kegiatan pemasaran dan promosi. Perusahaan harus memiliki keinginan keberanian untuk memfokuskan kegiatannya pada beberapa bagian saja (segmen) konsumen dan meninggalkan bagian lainnya.

\section{Positioning}

Positioning adalah strategi komunikasi yang berhubungan dengan bagaimana khalayak menempatkan suatu produk, merek, atau perusahaan di dalam otaknya, didalam alam khayalnya, sehingga khalayak memiliki penelitian tertentu. pengelohan pemasaran harus mengetahui bagaimana konsumen memproses informasi, menciptakan persepsi, dan bagaimana persepsi mempengaruhi pengambilan keputusannya.

\section{Persaingan Pasar}

Istilah pasar mengandung pengertian beraneka-ragam. Stantom, Et Al, (1994) mendefinisikannya sebagai tempat pertemuan antara penjual dan pembeli, barang atau jasa yang ditawarkan untuk dijual, dan terjadinya perpindahan kepemilikannya (dalam Tjiptono, 2008:59). Pembeli sebagai sebuah kelompok menentukan permintaan sebuah produk atau jasa tertentu, pembeli sebagai sebuah kelompok menentukan penawaran dari produk tersebut.

Persaingan pasar dibedakan menjadi dua, yakni persaingan pasar sempurna dan persaingan pasar tidak sempurna. Persaingan pasar sempurna adalah sebuah jenis pasar dengan dua karakteristik, yaitu barang yang dijual adalah sama dan pembeli dan penjual begitu banyak sehingga tidak ada satu pembeli atau penjual yang dapat mempengaruhi harga pasar, karena pembeli dan pejual dalam pasar persaingan sempurna harus menerima harga yang ditentukan oleh pasar, dan mereka disebut penerima harga (Mankiw, 2014: 62-63). Sedangkan persaingan pasar yang tidak sempurna adalah pasar yang tidak terorganisasi secara sempurna, atau bentuk pasar dimana salah satu ciri dari pasar pesaingan sempurna tidak terpenuhi.

Ada tiga jenis pasar kompetitif tidak sempurna. Pasar monopoli, pasar oligopoli dan pasar monopolistik. Sebuah perusahaan disebut monopoli jika perusahaan ini merupakan penjual tunggal produk atau barangnya dan jika produknya tidak memiliki subtitusi atau pengganti yang mirip, contoh pasar monopoli adalah PLN dan Microsoft Corporation (Mankiw, 2014:312). Oligopoli adalah pasar yang didalamnya terdapat sedikit penjual, yang masingmasingnya menawarkan produk serupa atau sama, contohnya adalah pasar bola tenis dan pakaian. Monopolistik menggambarkan struktur pasar dimana ada banyak perusahaan menjual produk yang serupa, tetapi tidak sama. Contohnya adalah PT Mustika Ratu yang bergerak di bidang kosmetik. Dalam pasar kompetitif monopolistik setiap perusahaan memiliki monopoli atas produk yang dibuatnya, tetapi banyak perusahaan lainnya membuat produk serupa dan memperebutkan pelanggan- 
pelanggan yang sama (Mankiw, 2014: 346).

\section{METODE PENELITIAN}

Pada penelitian ini, peneliti menggunakan metode kualitatif dengan penyajian analisis secara deskriptif yang dipaparkan kedalam bentuk deskripsi menurut bahasa, cara pandang, subjek penelitian yang berkenaan dengan masalah yang diteliti. Didalam penelitian deskriptif hanya memaparkan peristiwa, tidak menjelaskan hubungan, tidak menguji hipotesis, atau membuat prediksi (Rakhmat, 2004:24).

Dengan kata lain, penelitian ini disebut penelitian kualitatif karena merupakan rincian yang tidak mengadakan perhitungan (Moleong, 2005:34). Keuntungan dalam menggunakan penelitian kualitatif yaitu dapat dilihat realitas sosial yang merupakan upaya menyajikan dunia sosial dan prespektifnya didalam segi konsep, perilaku, dan persoalan tentang manusia yang teliti (Moleong, 2005:6).

Jumlah subjek dalam penelitian ini adalah 5 orang. Teknik pemilihan subjek utama yang digunakan adalah purposive sampling, dimana peneliti cenderung memilih informan yang dianggap tahu dan dapat dipercaya untuk menjadi sumber data dan telah cukup lama bekerja di PT Mustika Ratu Cabang Pekanbaru sehingga mengetahui masalah terkait komunikasi pemasaran PT Mustika Ratu secara mendalam. Lima orang tersebut adalah:

1. Manajer Area Mustika Ratu Cabang Pekanbaru, karena manajerlah yang mengkoordinir seluruh bawahannya dan mempunyai wewenang atas promo-promo produk yang ditawarkan untuk meningkatkan hasil penjualan.

2. Satu orang BC (Beauty Consultant) yang bertugas mempromosikan produk.
3. Satu orang BA (Beauty Advisor) yang bertugas menjual produk di toko-toko kosmetik.

4. Dua orang konsumen produk Mustika Ratu sebagai informan tambahan.

Dalam mengumpulkan data, peneliti menggunakan teknik observasi, wawancara (interview), dan dokumentasi. Selanjutnya peneliti menggunakan teknik triangulasi sebagai teknik pemeriksaan keabsahan data.

Analisis data sangat diperlukan oleh seorang peneliti dalam memecahkan kasus yang ditelitinya karena tanpa analisa data, peneliti akan mengalami kesulitan dalam menyelesaikan penelitiannya. Dalam proses analisis data yang akan dilakukan, peneliti menggunakan analisis data model interaktif Miles dan Huberman.Model analisis data interkatif terdiri dari tiga hal utama, yaitu reduksi data, penyajian data, dan penarikan kesimpulan (verifikasi) (dalam Nasution, 2003: 126).

\section{PEMBAHASAN}

\section{Strategi Komunikasi Pemasaran PT Mustika Ratu Cabang Pekanbaru Menghadapi Persaingan Pasar Kosmetik}

Dalam melakukan komunikasi pemasaran, PT Mustika Ratu Cabang Pekanbaru membuat berbagai macam program-program atau rencana komunikasi pemasaran untuk menghadapi persaingan pasar kosmetik. Sebelum itu, PT Mustika Ratu Cabang Pekanbaru terlebih dahulu menentukan segmentasi, target pasar dan positioning pemasaran PT Mustika Ratu Cabang Pekanbaru. Philip Kotler (dalam Morissan 2010:55-74) mengatakan ada 3 langkah yang harus dilakukan agar komunikasi pemasaran berhasil yakni dengan menentukan Segmentasi, Targetting dan Positioning (STP). Perencanaan strategi pemasaran dan 
pemilihan target pasar memberikan petunjuk kepada perusahaan mengenai siapa pelanggan yang akan menjadi fokus kegiatan pemasaran serta apa kebutuhan mereka yang belum terpuaskan. Kegiatan segmentasi pasar yang dilakukan PT Mustika Ratu Cabang Pekanbaru adalah mengelompokkan beberapa produk mustika ratu, seperti produk brand Puteri ditujukan bagi kalangan remaja, produk brand Bask dikhususkan bagi kalangan laki-laki, produk brand Ratu Mas ditujukan bagi perempuan dewasa dan produk brand Biocell ditujukan bagi kalangan menengah keatas. Selanjutnya, PT Mustika Ratu Cabang Pekanbaru menargetkan pemasarannya kepada masyarakat menengah keatas sesuai dengan kualitas mustika ratu yang berbahan alami dan diolah secara modern. Untuk positioning, PT Mustika Ratu Cabang Pekanbaru memposisikan citranya di mata masyarakat sebagai produk berbahan alami, yang kandungan kimianya rendah dan diolah secara modern. Dengan menentukan segmentasi, targeting, dan positioning, PT Mustika Ratu Cabang Pekanbaru dapat memfokuskan sumber daya yang dimilikinya terhadap segmen pasar yang paling menguntungkan, dapat melakukan focus dalam menganalisa kompetitornya, dan dapat menciptakan persepsi yang baik dari masyarakat ke PT Mustika Ratu Cabang Pekanbaru.

\section{Melalui Kegiatan Periklanan}

PT Mustika Ratu Cabang Pekanbaru melakukan kegiatan periklanan melalui media cetak dan elektronik. Kegiatan periklanan dilakukan agar masyarakat mengetahui informasi terbaru tentang produk mustika ratu. Melalui media cetak, PT Mustika Ratu Cabang Pekanbaru melakukan kegiatan periklanan dengan memberikan kalender, brosur dan katalog Mustika Ratu ke masyarakat, sehingga secara tidak langsung PT Mustika Ratu Cabang Pekanbaru mengiklankan produknya sendiri. Selanjutnya melalui media elekronik, PT Mustika Ratu Cabang Pekanbaru melakukan periklanan melalui media radio Riau FM untuk menjangkau masyarakat Riau dalam memperkenalkan produk-produk Mustika Ratu. Hal ini sudah sesuai dengan definisi periklanan menurut Kotler \& Keller (2008: 244), yang menyatakan bahwa salah satu karakteristik periklanan adalah dapat mencapai konsumen yang terpencar secara geografis.

$\begin{array}{lll}\text { 2. Melalui Kegiatan Promosi } & \\ \text { Penjualan } & & \end{array}$

Dalam kegiatan promosi penjualan, PT Mustika Ratu Cabang Pekanbaru mempergunakan alat promosi penjualan dengan cara membagikan sampel produk Mustika Ratu yakni berupa jamu kepada pengunjung di Car Free Day setelah pengunjung melakukan olahraga atau melakukan jalan santai. Hal ini bertujuan agar masyarakat mencoba produk mustika ratu dan merasakan manfaatnya sehingga pengujung tertarik membeli produk jamu-jamuan mustika ratu. Mengadakan End Year Sale Promo yang maksudnya setiap akhir tahun PT Mustika Ratu Cabang Pekanbaru memberi diskon atau potongan harga. Pemberian diskon dan potongan pada akhir tahun ini dilakukan agar lebih menarik perhatian konsumen dalam membeli produk mustika ratu, karena biasanya pada akhir tahun setiap orang lebih banyak menghabiskan waktunya di pusat perbelanjaan. Selanjutnya melakukan buy one get one promo, misalnya pembelian produk mustika ratu berukuran besar bonus produk mustika ratu berukuran kecil. Hal ini dilakukan untuk manarik konsumen agar membeli produk mustika ratu, karena biasanya konsumen lebih tertarik dengan produk gratis. Kegiatan promosi penjualan ini setiap bulan selalu dilaksanakan oleh pihak PT Mustika Ratu Cabang Pekanbaru, namun tidak memiliki hari 
khusus untuk mengadakan promosi penjualan kecuali End Year Sale yang diadakan setiap akhir tahun. Alat promosi penjulan yang digunakan oleh PT Mustika Ratu Cabang Pekanbaru adalah mengadakan seminar kecantikan. Seminar kecantikan adalah kegiatan demonstrasi produk mustika ratu yang dilakukan oleh Beauty Consultant ke instansi pemerintah, instansi swasta, maupun demontrasi yang dilakukan di perkumpulan ibu-ibu arisan dan ibu-ibu bhayangkari. Kegiatan demontrasi ini dilakukan dengan cara menjelaskan secara langsung keunggulan produk kosmetik Mustika Ratu, melakukan demonstrasi cara pemakaian produk kosmetik Mustika Ratu serta menjelaskan promo yang sedang berlaku. Hal ini tentunya bisa mejadi alat promosi penjualan yang efektif untuk mengenalkan produk mustika ratu dan keunggulannya kepada konsumen. Hal ini sesuai dengan definisi (Kotler, 2008:117) Promosi penjualan adalah insentif jangka pendek untuk mendorong pembelian atau penjualan produk atau jasa.

\section{Melalui Kegiatan Humas Dan Publisitas}

PT Mustika Ratu Cabang Pekanbaru melakukan kegiatan hubungan masyarakat dan publisitas yakni dengan mengadakan seminar-seminar edukasi kecantikan melalui beauty consultant kepada masyarakat. Beauty consultant menjelaskan kepada masyarakat bahwa produk dari PT Mustika Ratu Cabang Pekanbaru adalah produk alami, bebas dari bahan kimia yang berbahaya dan juga diolah secara modern. Kegiatan seminar ini juga menjadi ajang tanya jawab antar beauty consultant dan konsumen ataupun calon konsumen, sehingga kesalahpahaman konsumen tentang produk mustika ratu bisa diatasi dengan program ini. Hal ini sesuai dengan definisi humas dan publisitas menurut Philip Kotler (dalam
Hermawan, 201: 56) yang menyatakan bahwa Hubungan Masyarakat dan Publisitas merupakan program untuk mempromosikan dan/atau melindungi citra perusahaan atau produk individualnya. Kegiatan hubungan masyarakat dan publisitas yang dilakukan PT Mustika Ratu Cabang Pekanbaru lainnya adalah dengan rutin memberikan facial gratis kepada konsumen yang berbelanja minimal Rp. 100.000,- dan juga memberikan kalender, baju ke toko-toko dan konsumen menggunakan mobil kerja Mustika Ratu yang mudah dikenali oleh masyarakat. Dengan adanya kegiatan hubungan masyarakat ini, PT Mustika Ratu Cabang Pekanbaru dapat memperkenalkan secara luas produkproduknya ke masyarakat secara langsung dan juga dapa membangun citra yang baik bagi perusahaan. Hal ini sesuai dengan pernyataan Kotler dan Amstrong (2008: 168) yang menyatakan bahwa humas dan publisitas adalah kegiatan membangun hubungan baik dengan berbagai masyarakat perusahaan dengan memperoleh publisitas yang diinginkan, membangun citra perusahaan yang baik, dan menangani atau menghadapi rumor, cerita, dan kejadian tak menyenangkan.

\section{Melalui Kegiatan Personal Selling}

PT Mustika Ratu Cabang Pekanbaru melakukan kegiatan personal selling dengan cara mempresentasekan secara langsung keunggulan dan cara pemakaian produk mustika ratu. Kegiatan ini dilakukan oleh beauty consultant dengan cara mendemonstrasikan secara langsung kegunaan, keunggulan dan cara pemakaian produk mustika ratu. Beauty consultant yang melakukan pemasaran langsung diwajibkan menguasai materimateri atau isi katolog yang akan disampaikan kepada konsumen atau calon dan konsumen. Beauty consultant 
juga harus memahami keunggulan dan kekurangan dari produk yang dipasarkan, dan juga komunikator harus menawarkan produk-produk yang sedang mengalami diskon atau mendapat potongan harga sebagai strategi penjualan personal untuk menarik konsumen mustika ratu. Kegiatan personal selling yang telah dilakukan tim mustika ratu sudah sesuai dengan definisi personal selling menurut Kotler dan Amstrong (2008: 182) yang menyatakan bahwa penjualan personal adalah presentase pribadi oleh wiraniaga perusahaan dengan tujuan melakukan penjualan dan membangun hubungan dengan pelanggan. seperti promosi langsung atau menjelaskan langsung langsung kepada calon pembeli dengan tatap muka.

\section{Melalui Kegiatan Pemasaran Langsung}

Dalam memasarkan secara langsung produk mustika ratu kepada konsumen, PT Mustika Ratu Cabang Pekanbaru menggunakan tim Beauty Consultant dan Beauty Advisor. Beauty Advisor berinteraksi langsung dengan konsumen ataupun calon konsumen dalam memasarkan produk mustika ratu di swalayan ataupun pusat perbelanjaan seperti mall. Beauty Consultant juga berinteraksi langsung dengan konsumen dan calon konsumen dalam memasarkan produk mustika ratu melalui kegiatan demonstrasi ke instansi-instansi ataupun ke rumahrumah warga dalam acara arisan maupun perkumpulan ibu-ibu. Selain itu, Beauty Consultant dan Beauty Advisor juga memberikan brosur atau katalog yang berisi produk-produk yang sedang mengalami promosi seperti penurunan harga dan diskon belanja disertai dengan keunggulan produkproduk tersebut. Hal itu sangat efektif sekali, karena dengan memberikan brosur dan katolog secara langsung ke konsumen maupun calon kosumen dapat mempermudah para calon konsumen dan konsumen mengetahui informasi tentang keunggulan produk dan manfaat produk mustika ratu. Pemberian katalog dan brosur ini dilakukan oleh Beauty Consultant dan Beauty Advisor PT Mustika Ratu Cabang Pekanbaru dalam melakukan pemasaran langsung (direct marketing). Hal ini sesuai dengan definisi pemasaran langsung menurut Kotler dan Amstrong (2008: 221) yang menyatakan bahwa pemasaran langsung (direct marketing) adalah hubungan langsung antara pemasar dengan pelanggan, satu persatu dan bersifat interaktif, dilakukan secara langsung maupun via surat, telepon, email, faksmili dan alat penghubung nonpersonal lain untuk berkomunikasi secara langsung dan mendapat tanggapan langsung dari pelanggan.

\section{Melalui Kegiatan Acara Dan Pengalaman}

Untuk kegiatan acara dan pengalaman, PT Mustika Ratu Cabang Pekanbaru melakukannya dengan cara mensponsori ajang-ajang pencarian bakat seperti Bujang Dara Pekanbaru pada tahun 2014 dan pemilihan Puteri Indonesia wilayah Riau setiap tahunnya. Dengan begitu, tanpa sengaja PT Mustika Ratu Cabang Pekanbaru dikenal masyarakat sebagai perusahaan kosmetik yang peduli dengan kegiatankegiatan positif yang dilakukan oleh masyarakat Riau. Hal ini tentunya baik untuk membangun citra PT Mustika Ratu Cabang Pekanbaru di mata masyrakat. Selain menjadi sponsor di ajang-ajang pencarian bakat, PT Mustika Ratu Cabang Pekanbaru juga mengadakan senam zumba bersama masyarakat. PT Mustika Ratu Cabang Pekanbaru ingin menunjukkan bahwa ia dengan masyarakat Riau yang lebih sehat. Untuk menarik minat masyarakat dengan mengadakan senam zumba bersama, PT Mustika Ratu Cabang Pekanbaru memberikan doorprize 
kepada masyarakat yang beruntung. Dengan melakukan berbagai event dan menjadi sponsor dari event-event yang menarik perhatian masyrakat, tentunya PT Mustika Ratu Cabang Pekanbaru sebagai perusahaan produk kecantikan mendapatkan kesan baik dari masyarakat. Hal ini sesuai dengan definisi acara dan pengalaman menurut Philip Kotler (dalam Hermawan, 2012: 56) yang menyatakan bahwa acara dan pengalaman adalah pengembangan publisitas yang mengacu pada pengadaan kegiatan organisasional yang sifatnya mendukung promosi.

Faktor-Faktor Yang Mempengaruhi Komunikasi Pemasaran PT Mustika Ratu

$\begin{array}{ccr}\text { Secara } & \text { garis besar } & \text { seluruh } \\ \text { rangkaian } & \text { kegiatan } & \text { Integrated } \\ \text { Marketing } & \text { Communication } & \text { sudah }\end{array}$ dilakukan dengan baik oleh PT Mustika Ratu Cabang Pekanbaru. Namun tentunya masih ada factor-faktor yang mempengaruhi PT Mustika Ratu Cabang Pekanbaru dalam melakukan kegiatan komunikasi pemasaran terpadu.

Yang pertama adalah dari segi iklan di televisi yang dirasa karyawan maupun konsumen mustika ratu masih kurang, walaupun PT Mustika Ratu Cabang Pekanbaru sudah melakukan kegaiatan periklanan melalui radio Grees 105.8 FM. Hal ini diakui oleh manajer area PT Mustika Ratu Cabang Pekanbaru bahwa budget untuk iklan dirasa lebih efektif jika dialihkan untuk promosi penjualan.

Yang kedua adalah PT Mustika Ratu Cabang Pekanbaru masih kekurangan anggota dalam melakukan kegiatan komunikasi pemasaran, terutama dalam melakukan kegiatan promosi penjualan. Hal ini disebabkan karena beauty advisor yang dimiliki PT Mustika Ratu Cabang Pekanbaru hanya berjumlah 3 orang. Sedikitnya jumlah anggota team PT Mustika Ratu Cabang Pekanbaru disebabkan dulu pernah terjadi pengurangan karyawan dari pusat dan juga seiring waktu berjalan banyak karyawan yang resign. Yang ketiga, macetnya pendistribusian produkproduk mustika ratu ke toko, sehingga terjadinya kekosongan stok yang ada di toko.

Yang terakhir, PT Mustika Ratu Cabang Pekanbaru tidak begitu royal memberikan sampel produk kepada kosumen maupun calon konsumen jika dibandingkan dengan produk kosmetik lain. Hal ini tentunya bisa membuat calon konsumen dan konsumen mustika ratu menjadi enggan untuk membeli produk mustika ratu, dan lebih tertarik membeli produk lainnya.

\section{KESIMPULAN}

Berdasarkan hasil penelitian dan pembahasan mengenai komunikasi pemasaran PT Mustika Ratu Cabang Pekanbaru dalam menghadapi persaingan pasar kosmetik yang telah dipaparkan pada bab sebelumnya, serta berdasarkan permasalahan yang terjadi dilapangan dengan menggunakan teknik analisa yang telah di tentukan, dapat peneliti analisis dan simpulkan bahwa dalam melakukan komunikasi pemasaran, PT Mustika Ratu Cabang Pekanbaru membuat berbagai macam program-program atau rencana komunikasi pemasaran untuk menghadapi persaingan pasar kosmetik. Sebelum itu, PT Mustika Ratu Cabang Pekanbaru terlebih dahulu menentukan segmentasi, target pasar dan positioning.

Meskipun perencanaan telah dilakukan sebaik mungkin, namun tentu saja terdapat faktor-faktor yang mempengaruhi komunikasi pemasaran yang dilakukan PT Mustika Ratu Cabang Pekanbaru tidak dapat maksimal. Faktor-faktor tersebut adalah:

a. Periklanan di media televisi yang masih kurang. 
b. Masih kurangnya anggota dalam melakukan komunikasi pemasaran untuk mengahadapi persaingan pasar kosmetik.

c. Kurang royalnya PT Mustika Ratu Cabang Pekanbaru dalam memberikan sampel produk kepada konsumen maupun calon konsumen jika dibandingkan dengan produk lain.

d. Pendistibusian produk-produk mustika ratu yang macet sehingga terjadinya kekosongan stok

\section{DAFTAR PUSTAKA}

Alifahmi, Hifni. (2005). Sinergi Komunikasi Pemasaran. Integrasi Iklan, PR dan Promosi. Jakarta: Quantum

Hermawan, Agus. (2012). Komunikasi Pemasaran. Jakarta: Erlangga.

Kotler, Keller. (2008). Manajemen Pemasaran Jilid 2. Jakarta: Erlangga.
Kotler, Armstrong. (2008). PrinsipPrinsip Pemasaran Jilid 1. Jakarta: Erlangga.

Kriyantono, Rakhmat. (2006). Teknis Praktis Riset Komunikasi. Jakarta: Kencana.

Mankiw, Gregory. (2012). Pengantar Ekomoni Mikro. Jakarta: Salemba Empat.

Moleong, Lexy J. (2005). Metode Penelitian Kualitatif. Bandung: Remaja Rosda Karya.

Morissan. (2010). Periklanan: Komunikasi Pemasaran Terpadu. Jakarta: Kencana.

Nasution, S. (2003). Metode Naturalistik Kualitatif. Bandung: Tarsito.

Rakhmat, Jalaludin. (2004). Metode Penelitian Komunikasi. Bandung: Remaja Rosda Karya

Shimp, Terence. (2003). Periklanan Promosi. Jakarta: Erlangga

Tjiptono, Fandy. (2008). Strategi Pemasaran. Yogyakarta: Andi. 